E 99

.E7 H23 
140

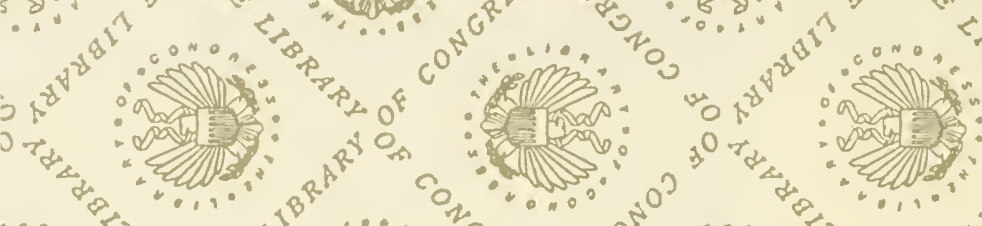

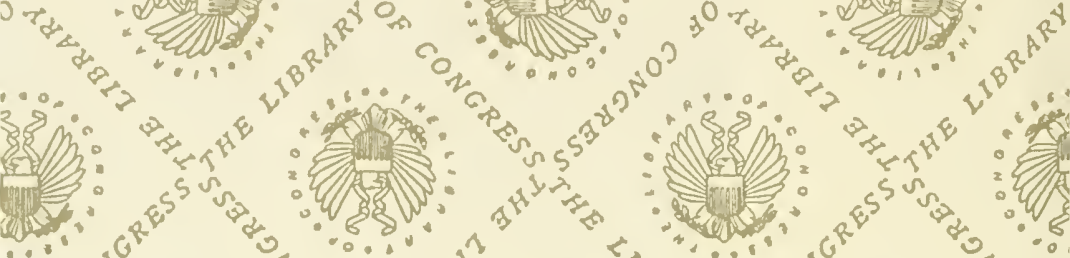

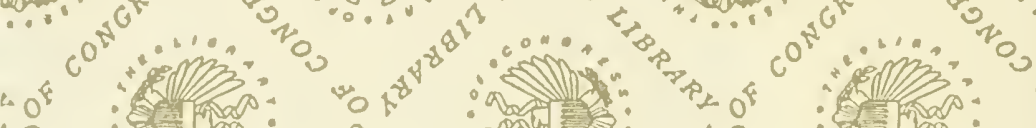

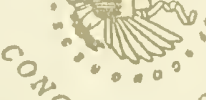

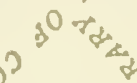
(a)
(a)

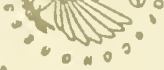

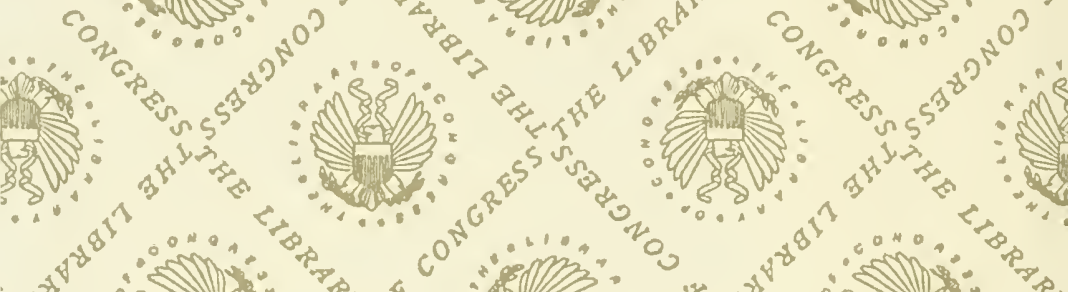

. ats $0^{8}$

c.

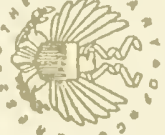

(

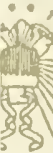

(s)

年

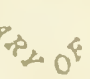

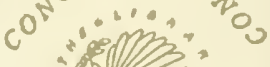


(Ins:

$2 \pi$

arom.

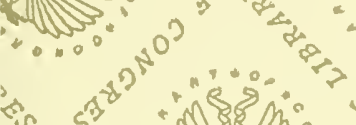

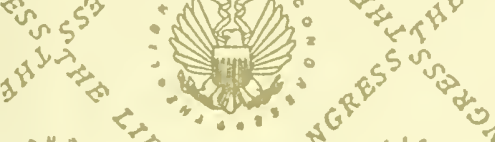

all

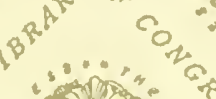

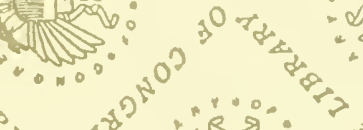

1.

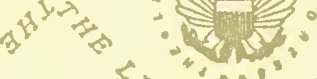

S

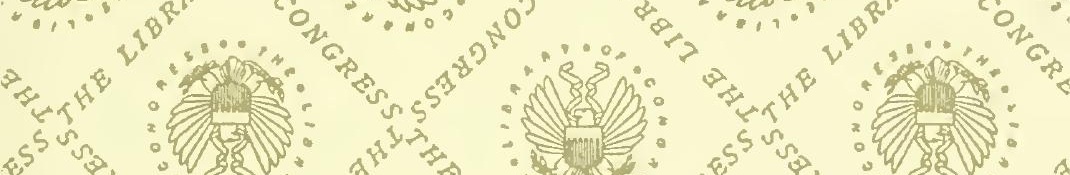
$\left.5^{s \omega^{2}}\right)^{3}$

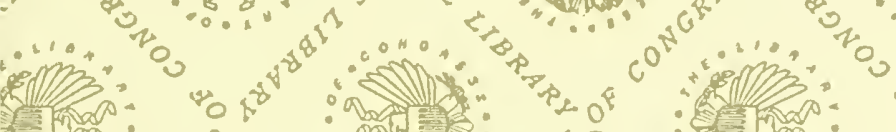
$=200:$

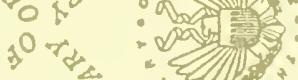

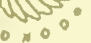
$0^{2}$

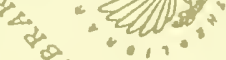
10
$4 O^{2}$

$\sin$

$3+2$

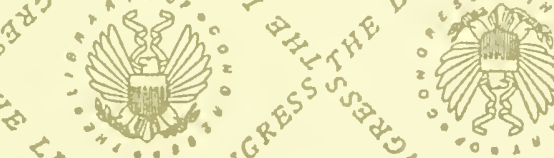

nUn

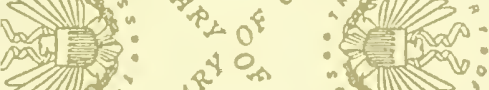



THE BEGINNINGS

OF THE

\title{
Moravian Mission IN
}

\author{
A LASKA.
}

BY

J. TAYLOR HAMILTON. 


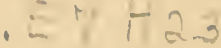

THE COMENIUS PRESS, BETHLEHEM, PA.

- 1890.

Exchango

West. Res. Hist. Soc.

1815

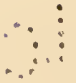




\title{
THE BEGINNINGS
}

\author{
OF THE
}

\section{MORAVIAN MISSION IN ALASKA.}

GOD in His providence lights the torch of missionary zeal in ways unforeseen by men. Count Zinzendorf is present at the Capital of Denmark for the Coronation of King Christian VI, and a negro, Anthony by name, a Christian slave, gives the impulse which leads to the establishment of the first foreign mission of the Moravian Church-that on the Island of St. Thomas. John Eliot is possessed of the idea that the Indians of North America are the descendants of the lost trubes of Israel ; and this inner conviction is for him a call constraining him to become their apostle. The British and Foreign Bible Society, a mighty engine for generating the electric light of gospel knowledge, takes its start from an overpowering hunger for the Word on the part of a poor girl in an obscure village of Wales. And so, too, the commencement of a 'Moravian Mission in Alaska was quite unforeseen by the members of that Church until within a year of its actual inception; and the call came from an unexpected quarter, was a Macedonian cry from another denomination of Protestant Christians.

At the annual meeting of the Moravian "Society for Propagating the Gospel among the Heathen," held on August 23, I 883, at Bethlehem, Penna., its President, the late Bishop Edmund de Schweinitz, communicated a letter from the Rev. Sheldon Jackson, D.D., of New York, then Secretary of the Board of Missions of the Presbyterian Church, ${ }^{x}$ in which he urged the establishment by the

${ }^{x}$ Now Territorial Superintendent of Education in Alaska. 
Moravian Church of a mission in Alaska among the Indians and Eskimos. The writer considered the Moravian Church to be especially fitted for this much-needed work, in view of the long experience of Moravian missionaries in evangelizing tribes of degraded savages; and stated that he had unsuccessfully applied to other denominations on behalf of the neglected heathen there, who are supposed to number about 15,000 .

The Society, whose organization dates back to the year I 787, having favorably entertained Dr. Jackson's appeal, and the approval of the Board charged with the general management of the Moravian Missions having been obtained, the authorities of the Church in America appointed the Rev. A. Hartmann, Moravian missionary among the Indians in Canada, and Mr. Wm. Weinland, a member of the graduating class of the Moravian Theological Seminary at Bethlehem, Penna., to undertake a tour of exploration in the Western part of the little known territory of Alaska.

A passage was secured for them on the U. S. Revenue Cutter Corwin, various officials connected with the Marine Revenue Bureau and the Coast Survey expressing their interest, and stating that the Government would welcome all the information the explorers might be able to gather about the inhabitants, flora, fauna and geological features of Western Alaska.

On reaching San Francisco, their credentials and recommendations secured them a most courteous reception from the officers of the Comvin, Lieutenant M. A. Heely, commanding. In the "Alaska Commercial Company" they found a very friendly corporation, its officers treating them most kindly, and giving them letters to their agents at various places with instructions to help the missionaries in every way possible.

The vast territory of Alaska, purchased from Russia in I 867 by the United States Government, comprises the whole of the Continent west of $\mathrm{I}_{4} \mathrm{1}^{\circ}$ west longitude and also numerous islands along the Coast. Its extreme length, from north to south is 1100 miles, and its greatest breadth from east to west is 800 miles, the entire area being estimated at 514,700 square miles. Its coast-line, owing to 
the frequent indentations, is greater than that of the eastern coast-line of the United States, being 7,860 miles in length. Its chief river, the Yukon, which rises in British territory, is another Mississippi for length and volume of water. Mighty mountains extend along the southern and western coast, out into the peninsula which gave the territory its name, some of them volcanic, and many capped with eternal snows. The climate of the southwestern part is comparatively mild, owing to the warm current of the Pacific, which also causes an excessive rain-fall. The wisdom of the purchase of the Territory as a financial measure has already been strikingly vindicated in the revenue derived from the monopoly of the catch of seals. The abundance of fur-bearing animals; the salmon and other fish that teem in its rivers; its primeval forests of cedar, spruce, larch, fir, cypress and hemlock and the deposits of coal and iron and other minerals that have been discovered, promise to render the value of the Territory yet greater when its resources shall have been more fully developed. Its central and northern portions remain as yet a terra incognita for the most part. The Indians who trap the animals in the interior are described as treacherous and discontented, where they have come in contact with whites; the Eskimos along the coast of the west, northwest and north, on the other hand, appear to be good-natured, though degraded and yery superstitious. Their belief in evil spirits and witchcraft renders them an easy prey of the "shaman," who figures among their tribes as does the "medicine-man" among the Indians.

Steaming out of San Francisco on May 3, the Corzoin reached Ounalaska on May 16 , and thence the explorers proceeded in the Dora, a steamer belonging to the Alaska Commercial Co., across Bering Sea to the mouth of the Nushagak River in Western Alaska. Here they found a Greek Church whose priest claimed the district of the Nushagak and Togiak Rivers as his parish. Hence they proceeded in the ship to the Kuskokwim River, at the mouth of which they arrived on June 12.

Up this river they traveled for about 150 miles in two large bidarkas, skin canoes each seating three persons, being 
paddled by natives. Their interpreter was a Mr. Lind, an agent of the Alaska Commercial Co. The natives they found approachable, very superstitious, very filthy, very loose in their estimate of the marriage relation, but kindly disposed, and on the whole honest, having very few possessions to tempt cupidity or prompt to theft, and living in utter disregard of the most ordinary laws of healih, so that lung diseases and scrofulous affections appeared to be very common. The land seemed to be flat, sandy soil on either side of the river, and was covered with tundra, a sort of mossy peaty bog, though wooded mountains appeared in the distance.

Retracing their way overland with the frequent use of bidarkas to Nushagak, the return voyage to San Francisco was made by the explorers in a sailing vessel, the Sadic $F$. Caller, without special event; and on September 25 they reached Bethlehem in safety, recommending that a mission station be founded on the Kuskokwim, about 75 miles from its mouth.

The Spring of 1885 sees a company of missionary pioneers in San Francisco, en route for Bethel, as this projected station is to be named. They are the Revs. $\mathrm{Wm} . \mathrm{H}$. Weinland and John Henry Kilbuck, ${ }^{2}$ recent graduates of the Moravian Theological Seminary, with their wives, and Brother Hans Torgersen, a practical carpenter, who goes with them as a lay-missionary for one year or longer to assist in establishing the Mission. He has left his wife at the Canada Indian Mission, where he has hitherto been engaged. They charter a schooner, the Lizzie Merrill, to convey themselves and their building material and supplies to the mouth of the Kuskokwim, taking with them a small sail-boat, the Bethel Star, with which to navigate that river. Weighing anchor on May i 8 , they leave the schooner on June 19.

And now let the narative of Brother Kilbuck tell of the

${ }^{2}$ Great-grandson of the Delaware chief, Gelelemend, born 1737 near Lehigh Gap, Northampton County, Penna., baptized in 1788 with the name William Henry, after Judge Henry, the Congressman, from whom he had once reccived a great favor; died a devoted Christian at Goshen, Ohio, in 1811 . 
heavy blow which fell upon the inexperienced young couples before their work was fairly begun :

"As soon as we had unloaded our goods, and made ourselves comfortable, the Brethren Weinland and Torgersen proceeded with a boat-load of lumber to Mumtrekhlagamute, in the vicinity of which we had determined to establish our first Mission. In due time the brethren returned, and we loaded all our provisions, and on the evening of July 3, we all started upon the last stage of our journey. Delayed by storms and calms, we did not reach our destination until July I 3. We were heartily welcomed by Mr. Lind, the trader at this post, and most hospitably entertained, until we were able to provide suitable accommodations for ourselves. On the evening of the I t th we selected the site for Bethel, which was a gentle rise about one halfmile west of the trading post. The place was chosen in the evening; and we knelt upon the tundra, led by Brother Torgersen, dedicated in prayer that spot unto the service of the Lord, and committed our plans and whole future into His hand. The remainder of the week was spent in unloading our boat, storing our goods, erecting our tent and a small frame building, I 2 X I 4 feet, which now serves as a work-shop and store-house.

A difficulty now presented itself, which caused us much thought and anxiety: we found our lumber to be very wet, and we well knew that we could not hope to build a warm house with material in that condition. It was a serious question, how to proceed; whether we should abandon the idea of building a frame house, and proceed, at once, to gather logs, and erect a log building large enough for comfort, or endeavor to make the best possible use of the material on hand, and not run the risk of being without good shelter, when Winter sets in. The Lord guided us in adopting the latter alternative. For Mr. Lind offered us the use of the Kashima, belonging to the post, for drying our lumber. We gladly accepted the offer, and set to work piling in the Kashima what lumber we had here. Quick hot fires were made morning and evening, and after the fire was put out, the building was entirely closed. In this way we hoped to get the lumber reasonably dry. With the help 
of a native, Brother Torgersen made a third trip to the mouth of the river, for more lumber. Favored with propitious winds, the entire trip was accomplished in four days.

Brother Torgersen and I left Bethel, July 28, after a fourth load of lumber, while Brother Weinland was to do what he could towards getting logs for the foundation, in addition to looking after the lumber in the Kashima. About this period we had great need of the strengthening power of faith. Brother Torgersen and I experienced one difficulty after another; were exposed to a pitiless storm for three days; and finally, August Io, when within sight of the station, Brother Torgersen fell overboard, and, before help could reach him, was drowned. I informed Brother Weinland of what had occurred, and asked him to come to my assistance. He sent word that he was sick in bed and therefore could not come. Owing to a calm, I was unable to proceed any farther, and furthermore, my eyes, which had been inflamed, now, that I was compelled to use them, became worse, and the pain almost unbearable; so according to instructions, I anchored the boat, made everything snug, and then getting into the birch canoe with a native I went home.

The meeting at home was sad, for we truly felt the hand of the Lord, but He granted unto us faith to look to Him for comfort and strength. The following day I went in a bidarka to the scene of the accident, and with the help of natives, dragged for the body, almost the entire day, but without success. It was not until five weeks after, that the body was found. It had been carried down an unfrequented channel, and cast upon an island and it was only by accident that it was discovered by a native. The remains of Brother Hans Torgersen now lie in peace on the summit of a hillock, to the west of the Mission House, from which can be seen the place, where according to his wish he died while upon the Lord's battle-field. "Whosoever shall lose his life for My sake and the Gospel's the same shall save it," is the promise of Him, to whom Hans Torgersen clave with all his strength."

The situation was indeed serious. Two young men, utterly inexperienced in house-building-the one, Weinland, 
having spent all his life at school, in college and in the seminary, the other, Kilbuck, a full-blooded Indian, who had as a lad left his home in Kansas to be educated in the church school at Nazareth, Pa., thence to take the classical and theological course at Bethlehem - with their brides of a few months, face to face with an arctic Winter, and not having a roof over their heads; Kilbuck, moreover, suffering from an affection of the eyes that at times almost blinded him; the material which they had brought for the construction of a house in such a condition from the frequent rains, that they doubted whether they could use it; and, to crown all, both of them able to communicate with the natives only by "sign language," except for the aid of Mr. Lind, the trader at the "post" of the Alaska Commercial Co. Less heroic souls might have searched for some possible means of a retreat. Not so, these missionary couples. They dry their lumber as best they can in the Kashima which Mr. Lind kindly places at their disposal. They erect their dwelling according to the best of their ability ; and it is taken possession of by them on October $\mathbf{~} 0$, having consecrated a neighboring hillock a few weeks before by the committal to its earth of the body of the elder companion on whom they had leaned and whose loss they so deeply mourned. Yet there was Another in Whom a more complete dependence was placed, for they write concerning this time of test, "You see that we can say, "The Lord is our Helper.'"

Thus their surroundings are described by them:

"The station is about 70 or 75 miles from the mouth of the river, and about one half-mile west of the Mumtrekhlagamute trading-post. The location is as healthful as it can be in Alaska, being on rather high ground, about twenty-five feet above river, and no swamps in the immediate vicinity. The country to the west and northwest is open tundra, while there is a considerable pinery to the north and northeast, which serves as a break to the winter winds. To the east we have the river and wooded islands, and in the distance the rugged mountains of Alaska can be seen. To the south is a channel of the river, and a large thickly wooded island which protects us from the heavy 
south 'winds. Good water is near at hand, an arm of the river being not more than sixty yards from us. Besides the above advantages we have the following, which have a direct bearing on our future work. Being near the trading - post, we get to see a great many natives from villages up and down the river, and on the tundra. The location is central. Taking a two day's' journey with a dog-team as a radius, we form the center of a circle, within whose limits may be found a population of 1200 natives, according to the lowest possible estimate."

The Winter, which soon set in, was unusually severe. In October neighboring lakes were like rock in the grasp of the arctic cold; and though warm waves at intervals marle the climate more endurable, it was the end of May before the river was clear of ice. Meantime medicine was practiced amongst the natives, whose language formed a constant study, and religious services were statedly maintained. In short, the Mission was being established. On January ro Elizabeth Louisa Weinland was born, the first white American child in the Kuskokwim District.

Meantime it had become evident to those charged with the administration of the Mission, that a station should be founded at Nushagak also, in order to secure more frequent communication with Bethel, there being five salmon-can. neries at the mouth of the former river visited several times a year by sailing vessels, whilst Bethel could be reached only twice a year. For this undertaking the Rev. Frank Wolff and wife, of Greenbay, Wis., volunteered; and their services being accepted, the former was sent in the Spring of I 886 to San Francisco to get together and have prepared materials for a mission-house and school, in such a way that the work of erection might proceed as rapidly as possible after they had been transported to Alaska. Greatly assisted by Christian friends, and receiving particular kindness from the president of the Arctic Fishing Co., Mr. Rholffs, whose vessel, the Sadie F. Caller, under the command of the same Captain who had brought the Brethren Hartmann and Wein]and back from Nushagak in $\mathrm{x} 88_{4}$, was to transport him and all his materials gratis, Brother IVolff sailed on July I 7 , reached Nushagak on 
August 21, located the Mission, and with the aid of the men of the above-mentioned Company put in place the $3 \mathrm{I}, 000$ feet of lumber and 20,000 shingles, so that the building, $24 \times 28 \times 9$ feet, could be locked and entrusted to the care of the native chief on September 8. The Arctic Fishing Co., through whose kind offices this expeditious result was rendered possible, placed the Moravian Church under a lasting debt of gratitude. Says Brother Wolff: "They in the first place made no charge for passage-money or freight on all the lumber from San Francisco to Nushagak. Nor did my return trip cost me a cent; for board, both ways, was free. In the second place, they charged only the actual cash outlay for the workmen's help. In the third place, they not only boarded myself and the workmen, free of all expense, while at Nushagak; but they supplied all the native assistants with free food, and one must have seen a native eat in order to form a just idea of what this item would amount to! Besides all this, was the constant kindness, which can not be reckoned in dollars and cents."

His return journey was speedy and prosperous, so that on October I I he was enabled to report in person at Bethlehem to the Board of Directors of the Society for Propagating the Gospel the successful carrying out of the instructions received in Spring.

On the tenth of May, I 887 , a missionary party consisting of the Rev. Frank Wolff and wife and Miss Mary Huber, of Lititz, Lancaster Co., Penna.-the latter, one of several lady volunteers-left San Francisco with the steamer of the Alaska Commercial Company for Nushagak by way of Ounalaska; and on their safe arrival at their destination, were able to send the welcome news that they found the Carmel Mission-house, as they named it, together with the many articles that had been stored there, untouched and in perfect condition.

Meantime the Winter of $1886-1887$ had been one of severe trial for the little company at Bethel. School had been opened on September 8, r886, and on the following Lord's Day a Sabbath-school had been commenced, both of which were steadily maintained. Severe lung troubles, 
however, incapacitated Brother Weinland much of the time from active work, and it soon became evident that the climate would prove fatal to him if he remained. There was no other way than for him to return with his family, who had also experienced severe sickness, in the Summer of $\mathrm{r} 887$. A specially unfortunate feature was, that it would be impossible to communicate with the authorities before his arrival in San Francisco, and too late therefore to send out re-enforcements before Winter to Brother and Sister Kilbuck. Hard though it would be for the latter couple, the inevitable had to be recognized.

Nevertheless, some progress had been made. During the Summer of 1886 , a second house $28 \times 24$ feet had been constructed out of logs rafted at four different times down the river, the last lot from a very great distance. The scholars, too, had made surprising progress, and by his constantly increasing knowledge of the Eskimo Brother Kilbuck had been preparing the ground for harvests of souls. Except on but few Sabbaths natives had always taken part in the services, and several had expressed a desire to know more of the teachings of the missionaries and were looking forward to the time when their tongues should be "light." The Christmas celebration with its lighted tree had made a great sensation throughout the whole district.

At length, however, there came the day of sad parting, when the ship of the Alaska Commercial Company, weighing anchor at the mouth of the Kuskokwim, bore away from the Kilbucks their only helpers, shattered in health, the hearty explorer of a few years ago broken down, it might be, for life. ${ }^{3}$

A weary, weary time must the early part of the IVinter of $\mathbf{1} 887$ to $\mathbf{r} 888$ have been at the lonely out-post of civil-

3 It is a satisfaction at this date, February, 1890 , to be able to write that Brother Weinland and his family gradually regained soundness of health on their return to the States, in 1889 were sent to labor amongst the Indians of Southern California, and are now beginning to reap a harvest of converts in the Ramona Valley rendered famous by Helen Hunt Jackson, their work at Potraro and Saboba having promise of a very hopeful future. 
ization and Christianity on the Kuskokwim. Work enough there was to do. At times troops of natives covered with boils, the heritage of a period of semi-starvation, clamor for salves and medicines; the school must be taught, its seventeen children clothed and fed-often washed, or even disinfected, when first received; there is a log-house to be built with native help; there are heavy parental anxieties about little Katie, the missionaries' child, and sometimes the utter cruelty of the unfeeling heathen is such that it would depress any except the stoutest-hearted. Here is an extract from the missionaries' Journal :

"Some one tied a helpless little child of about two years down to the water's edge at low tide. Its cries attracted the attention of a passer-by, who found the water already nearly up to his neck. The man took it to his home and took good care of it. It was recognized as a Neposkiogamute child, whose mother had died, the father leaving it in the care of an old woman at Mumtrekhlagamute. The child is sickly and doubtless was too much of a care for her. The only surprise that people have about it is, that any one should want to drown or kill a boy; their girls are often killed, but seldom a boy." . . . "At the mouth of the river, an old woman was cut up into small pieces by a man, who supposed he had lost his children through her witchery. Some time ago quite a prominent native brought an aunt down here. She was insane, and he was her only living relative. This man wished to leave her among strangers, and tried to bribe them to kill her. He was finally compelled to take her back to his home. We heard the other day that he deliberately froze her to death."

Yet the brave couple, though sometimes in ill-health, labor on undaunted. In spite of 30 degrees below zero, Brother Kilbuck will walk twenty-five or thirty miles to plan for the erection of chapels at two other villages. At one time, his nose and lips are frozen; at another, a blinding snowstorm meets him on his way home. There must sometimes be contests with the "shamans" who threaten him with their "black art."

But dawn is at hand. Day breaks soon after the darkest hour. At Christmas the interest taken in the "old, old 
story" by natives from far and near, gives promise of the light. Signs of morning are in the zenith, and soon the earth itself will be glorious with its effulgence. Moreover, through the mercy of God, the memory of it shall ever be associated with the memorial of the first bitter disappointment and grievous anxiety.

It is the Holy Week. Daily services, such as are customary throughout the Moravian world, have been commenced on Palm Sunday. Twice or even thrice a day there have been natives who are willing to listen for an hour and a half to two hours at a time to what of the language the missionary can command. It is Good Friday. He has reached the crucifixion, and is explaining that the blood shed by Jesus Christ on the cross was for the taking away of all sin, when some of the older men (praise God!) exclaim "Kou-já-nah! (Thanks). We, too, desire to have our badness taken away by that blood."

It is Easter Sunday, at day-break, and forty people have gathered about the grave of Brother Torgersen. They sing, in the native language, three hymns of the Resurrection. It seems the message, that He died for our sins and rose again for our justification, is balm for the wounds of the hearts of Eskimos, as well as of the Caucasians who have sent the messenger and of the Indian messenger who brings them the glad tidings. They leave the grave, having sung, "Praise God from whom all blessings flow."

A number of natives soon apply for membership in the Church-some have already months ago hinted at such a desire, before they realized the full significance of this step. A period of instruction and probation follows, and on September I0, I8S8, eight are gathered in as the first fruits of the Moravian Mission amongst the Eskimos in Alaska.

And yet they were not strictly speaking the first fruits. For at Carmel, on April 22 previous, a German sailor of about forty-five years of age, Louis Günther, who had been left in charge of the property of the Arctic Packing Company at Nushagak, and who had been led by the missionary to a knowledge of the truth as it is in Jesus, had been con 
firmed by Brother Wolff after careful instruction in the faith.

Here the work had been mainly of a preparatory nature. The house and school had to be fitted internally for the long and severe Winter, so that little missionary work proper was done before Christmas. Then, however, a school was opened, with the design of making prominent industrial features of instruction. The one drawback to success, apart from the difficulties of intercourse from an ignorance of the language, was the persistent opposition of the priest and the deacon of the Greek Church at Nushagak, who did not scruple to use fair means or foul to thwart the endeavors of the missionaries. Nor is there lack of labor in curing the physical ailments of those who come to the Mission-station, as to a hospital, with broken limbs, ulcers, running sores, boils or severe lung diseases.

Turning once more to Bethel, the heroic family there were not to pass another Winter entirely alone. On May, I 2, I 888, the Rev. Ernest Veber, of Gracehill, Iowa, who had volunteered and had been ordained for service in Alaska, left San Francisco, and arrived at his destination on June 16.

He is soon quite at home in his work, his arrival making it possible to hasten the erection of the log-house planned for a school and chapel. His impressions of a native "reception " at a village up the river, visited by him in search of logs, are full of graphic interest. He says :

"In the evening, the natives at this village had one of their dances, for my especial benefit. It is more of a feast than anything else. They had a great many berries; and as they did not have any clean dishes for me, they turned my hat inside out and filled it up for me. It is surprising how many some of them can eat; often half a gallon of salmon-berries. They also had their ice-cream ${ }^{4}$ and sour fish-heads, and dry fish. They had two young women to dance. I wish I could make you understand how it was. First the folks get everything ready. They stretch a cord all full of dried birds across the room, and

${ }^{4}$ Water-ice? 
stick them up everywhere. They have small birds on the cord and large ones on the wall, such as large owls. Then the boys and young men all get down in the middle of the room * * with sticks in their hands. They have two tambourines to beat time on. Then the women come in, all fixed up in grand style. One had a sharpened stick through her nose, and was all covered with beads. Then the singing began. It seemed more like an Indian wardance to me than anything else. The women would make all kinds of motions. They kept good time, and I must say it looked rather graceful. The boys keep time with their sticks. They do not strike anything, but just make motions. It lasted till about ten o'clock.'

At the beginning of December, he takes Brother Kilbuck's place as teacher in the school, for the latter on the third of the month starts off with a dog-team for a five weeks' visit to Carmel, where he would confer with the missionaries about their work. But though man may propose, it is God who disposes. The difficulties of travel and the heavy rains so prolong the journey thither, that Christmas has passed before he reaches the other Missionstation. Then, terrible storms and intensest cold delay the return. Seventy-three days elapse before he reappears at home, like one risen from the dead, "his hair and beard long and his face all covered with black spots where it had been frozen." It had been a miracle that he got through with his life. "No wood often but green willow brush to burn, and very little food to be gotten for his teams of fifteen dogs." Meantime his wife, worn out with overwork at home, had been seized with serious illness, and was confined for several weeks to her bed. Her feelings during the time of trial are thus recorded in a letter not written for print :

"Days and weeks went by. The weather was fearfully bad. One storm raged after another, with scarcely a day's intermission. We began to think seriously, when we remembered how much of his road lay among the mountains where there was no wood and where no natives lived. The thermometer showed as low as fifty-nine degrees below zero which is ninety-one degrees below the freezing point, and 
most bitter cold it was I can assure you. The snow was never seen half so deep in all our stay in Alaska; and yet as time, long, anxious time passed on, he did not come. The thirty-five days he expected to be gone were long past. Forty, fifty and sixty days were also gone and everybody began to hint to me that I must live without him. He never could or would return again. They said it was beyond all reason for him to be gone any more if he was still well and alive. Mr. Lind said, and I felt sure of it myself, that he would send us word, if any accident had occurred to detain him.

The days dragged heavily and seemed a week long, each of them. From this time on we felt that each added day only proved the reality of our fear. Sad indeed were the faces that greeted us at every turn, and sadder still our own. With hopeless despair we would turn from the window, that in spite of our fears held some magic attraction. We soon learned to not expect him even if we did look and look around the island's head, where he would first appear when he did come.

We had not forgotten the Source of all comfort and peace, and to Him we joyfully fled for consolation and grace to bear, what seemed to us, a burden too heavy for us. We were not disappointed in this kind and loving Friend. Our prayers were most abundantly answered, and as soon as we were willing to say "Thy will, not mine," the blessing came in a tenfold measure. How calm and peaceful were our troubled hearts then. We wondered at the grace that was poured out upon us daily and hourly. Never before did I feel the nearness and dearness of my Saviour so thoroughly. The future and its duty was plainly set before me. Brother Weber and I talked of plans for the future, and I promised to stay here as long as I could be of any use in the work. This seemed to be of much encouragement to him, for he was not willing to give up, and wished to stay working on, hoping that some one might be sent to Bethel this Spring. Our constant prayer was that the people of our Province would not, when they heard of the Mission's loss, become discouraged and slacken in the work of sujporting and cheering the workers in this 
important and promising field of labor. We ourselves were willing to remain and work on, to the best of our ability."

What joy attended the return of the one considered lost! Says Brother IVeber in his diary for February 14, 1 887 :

"When we least expect it, the Lord answers our prayers. This morning, about eleven o'clock, we saw two large teams come around the island. But we had so completely given up Brother Kilbuck, that I did not think of him. When I saw them, some of the boys said, "Who is that? Let's get the glass." Pretty soon they said they believed it was Brother Kilbuck. Then we all looked; but were afraid to say it was he, for fear we should be disappointed.

Mr. Lind was here. He said it was he. Pretty soon he waved his hand, and then we knew it was he; and words can not express the joy that we felt. Mr. Lind and I ran down to meet him. Mrs. Kilbuck and the children were standing by the house, waiting. And it just seemed as if Mr. Kilbuck had risen from the dead. I do not believe we should have felt happier if he had."

And the happiness of return was celebrated in a peculiarly blessed way, on the $24^{\text {th }}$ of the month, by the addition of ten of the scholars and four adults to the Church. The former, in the presence of a large number of their heathen relatives, boldly came forward and confessed their faith in Jesus.

The visit to Carmel had proved a very opportune one. The opposition of the Greek priest had thus far been most trying. On Thanksgiving Day a special dinner had been prepared for the scholars; but all except those who boarded in the Mission-house were ordered away by this spiritual tyrant. Again, at Christmas, the projected entertainment was rendered a comparative failure by similar manœuvers. Besides the comfort of sympathy at such a time, the ability of Brother Kilbuck to speak the Eskimo was a marvel and a stimulus to emulation.

But the memorable visit to Carmel served yet another purpose. It made it possible to send tidings of the IVinter in letters by the kind offices of Lord Lonsdale, an English nobleman who was about to close an adventurous tour in Arctic regions, which were received at Bethlehem, Pa., in 
February instead of in July as had been customary. Already the conviction had been deeply fixed in the minds of the Directors of the Society for Propagating the Gospel that additional help should be sent to both stations, and a call had gone forth for volunteers. Now, it appeared as though the brave woman who had so long toiled to the nitmost of her strength without female help at Bethel, might be compelled to return home, for a time at least. The news sent a thrill through the American Moravian Church. At least nineteen volunteers came forward for service in Alaska. Two were selected. John Herman Schœechert, of Watertown, Wisconsin, who was subsequently ordained, was appointed to go to Carmel ; and Miss Carrie Detterer, of Riverside, New Jersey, a daughter of a former pastor of the Moravian congregation there, was chosen for Bethel. In addition, the wife of Bishop Henry T. Bachman, one of the Provincial Elders of the American Moravian Church, offered to go to Bethel for one year, with her youngest son, so as to give Mrs. Kilbuck the rest she so niuch needed.

Accordingly this new company of missionaries sailed from San Francisco on May i 5, I 889, parting at Ounalaska, to arrive safely at their respective destinations about a week apart in June. Cheered by these reinforcements, the missionaries at either station could look forward to the new year of work with hopeful courage. At Bethel, health had been restored to Mrs. Kilbuck, so that her absence from her post was not required. About twenty children were attending the school, when the last letters were sent home. The little congregation numbered twenty-two, not counting the missionaries. At Carmel, the absence of the Greek priest, who had left for San Francisco, rendered labor more agreeable, though there was felt to be great lack of suitable accommodations for the scholars and for the new missionary. During the Summer the ministrations of Brother Wolff to the men of the canneries seemed to be not wholly resultless. Two of the girls of the school were moreover candidates for membership in the Church. The total number of scholars last October was thirty-one.

Such is the past of the Moravian Mission in Alaska. A great deal of the work has not yet developed into figures 
and statistics, having been largely of a preparatory nature. Yet it has been of such a sort that blessed results may be expected before long. Obstacles had to be removed, the ground broken, the seed sown, and then comes the blade, the ear, and the harvest. It takes years to break the ground, to acquire the language, to translate the Scriptures, establish schools, and to get the good seed sown into the minds and hearts of the people. As the Rev. J. Liggins says: "The true method for judging the result of missionary labor is not that which regards it like a prairie fire, that sweeps rapidly over the plains, devouring all within its range, and so swiftly dying out; but rather as a mighty silent influence, like the quiet, steady forces of nature, which carry the seed and deposit it in the soil, nursing it with sunshine and with rain year after year, until an oak springs up and reaches out its growing arms over the sod, and in time scatters the acorns, until a mighty forest waves its majestic boughs, where once were rocks and thistles."

The plans of the missionaries are comprehensive and definite, anticipating success. The request of Brother Wolff for 30,000 feet of prepared lumber to build a larger school-house and chapel at Carmel has been granted by the Board; and this material will be sent from San Francisco this Summer. Brother Kilbuck's suggestion, on the other hand, can scarcely be acted upon before an official visitation has been made, to judge of the field. Meantime, however, additional volunteers for Bethel are being asked for, to anticipate and prepare for any move. Besides, it is contemplated, if possible, to send two promising young Eskimos to Pennsylvania, to be there prepared for evangelistic work among their own people. The following is the plan of Brother Kilbuck for further operations, just alluded to:

"The Lord has put it into our hearts, to make the following suggestion to our brethren: Start a Mission-Station at Togiak Bay.

Why? For the following reasons:

$a$. The Togiak valley is a field as distinct as either Nushagak or Bethel. This field can not be reached easily from either of the two stations. A station at the mouth 
of the Togiak River will command its entire length, and will be able to reach natives, in number next to those on this river.

b. By placing a Mission-station at Togiak Bay the gap that is now between Nushagak and Bethel will be closed up, and we will thus take possession of a territory rich in souls. Furthermore, working hand in hand, each station will become a support to the others, and together as a phalanx they can storm the interior. Continuing the military figure, it is of the utmost importance to the success of the work, that one general should command the forces between here and Nushagak, under our great Captain. The manual of arms, and the marching tactics will then be the same; hence there will be no confusion.

c. A school can readily be gathered together. For in the village of Togiak there are fifty children of school age. The people there recognize the importance of educating their children, but are unwilling to send them either to Nushagak or Bethel, because it is too far from their homes.

d. A vessel comes right into the bay, and the goods are landed by her boats, as at Nushagak.

The above reasons are all in favor of a missionary enterprise at Togiak.

Now I will state its disadvantages.

a. Chief and foremost, is the lack of building material, and fuel. Building, however, will not cost any more than in the East, even if the lumber is shipped from San Francisco. I think that stone houses can be put up, as the mountains that come down to the water's edge are principally composed of rocks. Whether these stones can be used for building or not, I do not know, but it will be worth while to investigate the matter. As to fuel, there is an abundance of cottonwood timber a short distance up the river, which can be cut and dried. This timber is eight and ten inches in diameter. Besides, I think there must be coal in the interior, as I understand there are traces of coal 
found on the rivers that head on the mountains that divide the Togiak valley from the Kuskokwim.

b. The other difficulty is one that Nushagak has to contend with, the opposition of the Greek Church. It is, however, too far moved from that station for this opposition to prevent a rapid progress of evangelistic work.

These two are the only disadvantages that I know of. I have endeavored to give you a fair idea of this new plan for the extension of the Church's activity."

In case this suggestion can not be carried out, Brother Kilbuck desires to have the working force at Bethel so increased that without disadvantage to this central station outposts may be occupied at a greater or less distance as filials, and more or less extensive evangelistic tours be undertaken up and down the Kuskokwim River. For the latter purpose a steam launch such as the Society at its last annual meeting took into consideration to send, would doubtless prove extremely useful.

Such has been the commencement, and such is the present situation, of the Moravian Mission in Alaska. What its future is destined to be, the Lord, Whose coming to reign over His rightful dominion $H$ is faithful servants are seeking to hasten, alone knows, concealed as it is in the sovereign mystery of His providential designs. This, however, renlains certain: whatever that future, He will not put to shame the faith and fidelity of those who are in the field and of those who maintain them whilst "abiding by the staff" at home. To him be all the glory of success!

The control of the Moravian Mission in Alaska, belongs ultimately to the Department of Missions at Berthelsdorf, in Saxony, in accordance with the fundamental principle of the Moravian Church, that "the Brethren's Unity and the Brethren's Mission are inseparably connected, and that there will never be a Unity of the Brethren without a Mission to the Heathen or a Mission of the Brethren which is not an affair of the whole Church." Yet the practical 
management of this particular Mission, like that of the Moravian Mission among the Indians of North America, has been committed to the Provincial Elders' Conference of the northern division of the American Moravian Church, subject in matters of importance to the consent and approval of the higher Board. In financial matters and affairs of external administration respecting Alaska, the Provincial Elders' Conference is associated with the other members of the executive Board of the Society for Propagating the Gospel among the Heathen, which has its seat at Bethlehem, Pennsylvania.

The expenses of the mission, of necessity heavy-owing to the long journeys, the need of sending provisions and other supplies from San Francisco each Summer for the succeeding year, and the clothing and boarding of the school children-have been met mainly by voluntary contributions on the part of members and friends of the Moravian Church in America. These gifts have been promoted by the establishment, in various congregations of the Moravian Church in the same territory, of Alaska Societies Auxiliary to the Society for Propagating the Gospel. A number of Serving Societies have also systematically lessened the labor of the missionaries by their needle-work. In addition, comparatively small grants have been received from the U. S. Government in aid of the schools at Bethel and Carmel, which form a part of the public school system of the Territory.

From its inception to July $3 \mathrm{I}$, I 889 , the Mission has cost $\$ 27,234.86$. Of this sum, \$I9,273.28 have been met by voluntary contributions. The grants from Government have amounted to $\$ 2,600$. The remainder has been made up by appropriations from the interest of the funds of the Society for Propagating the Gospel, the rest of whose income is used for the support of Moravian Missions in general.

Gifts, either of money or clothing or of useful articles or books, for the Moravian Mission in Alaska may be sent to, and will be thankfully received by the Treasurer, the Rev. Robt. de Schweinitz, Bethlehem, Pennsylvania. 


${ }^{4}$

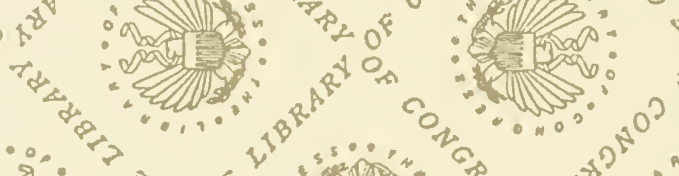

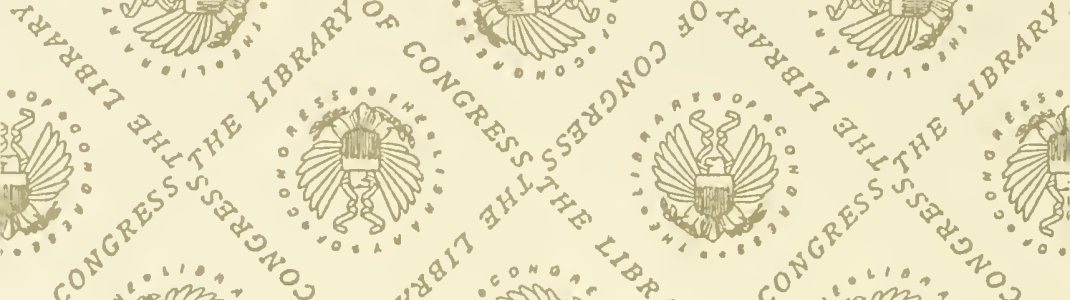

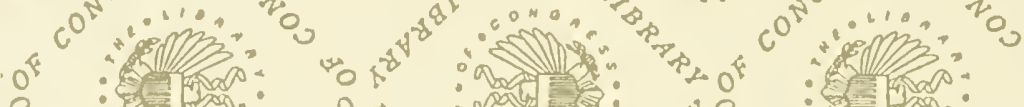
os
-
$3^{\circ} \mathrm{r}_{\mathrm{a}}$. Cul

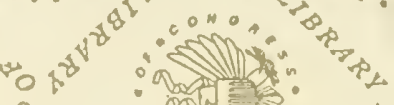

$x^{0} r_{2}$

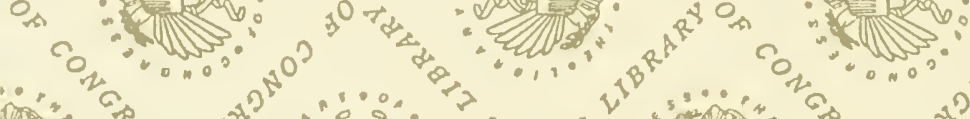

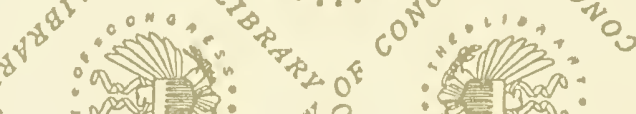

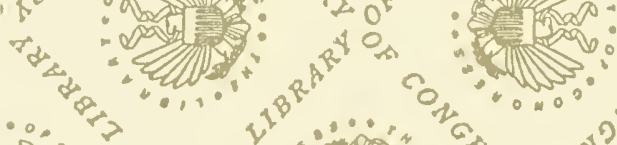

$35^{\circ} \cdot 0^{2}$

$0^{8}$

$0^{3}+\cdots \cdots$

s

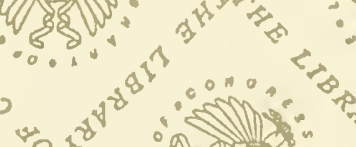
(ख):

o

$3_{3}^{\circ}+\mathrm{r}^{2}$

,

a

W

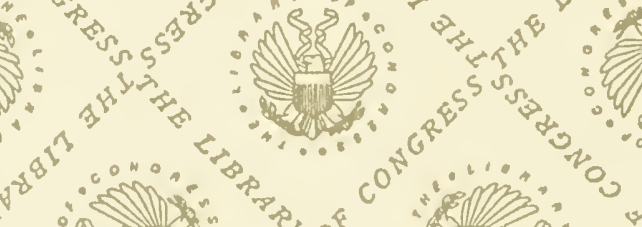

:

$40^{\circ}$

.

o $p_{\alpha}$ 
LIBRARY OF CONGRESS

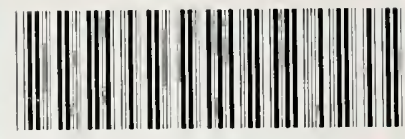
0010742832 A 